Article

\title{
Syntheses and Reactivity of New Zwitterionic Imidazolium Trihydridoborate and Triphenylborate Species
}

\author{
Maura Pellei ${ }^{1} \mathbb{D}$, Riccardo Vallesi ${ }^{1}$, Luca Bagnarelli ${ }^{1}$, H. V. Rasika Dias ${ }^{2, *}$ and Carlo Santini ${ }^{1, * \mathbb{C}}$ \\ 1 School of Science and Technology, Chemistry Division, University of Camerino, via S. Agostino 1, \\ 62032 Camerino, Macerata, Italy; maura.pellei@unicam.it (M.P.); riccardo.vallesi@unicam.it (R.V.); \\ luca.bagnarelli@unicam.it (L.B.) \\ 2 Department of Chemistry and Biochemistry, The University of Texas at Arlington, \\ Arlington, TX 76019-0065, USA \\ * Correspondence: dias@uta.edu (H.V.R.D.); carlo.santini@unicam.it (C.S.); Tel.: +390737402213 (C.S.); \\ Fax: +390737637345 (C.S.)
}

Academic Editor: Yves Canac

Received: 18 June 2020; Accepted: 10 July 2020; Published: 13 July 2020

\begin{abstract}
In this study, four new $N$-(alkyl/aryl)imidazolium-borates were prepared, and their deprotonation reactions were investigated. Addition of $\mathrm{BH}_{3} \bullet \mathrm{THF}$ to $\mathrm{N}$-benzylimidazoles and $\mathrm{N}$-mesitylimidazoles leads to imidazolium-trihydridoborate adducts. Ammonium tetraphenylborate reacts with benzyl- or mesityl-imidazoles with the loss of one of the phenyl groups yielding the corresponding imidazolium-triphenylborates. Their authenticity was confirmed by $\mathrm{CHN}$ analysis, ${ }^{1} \mathrm{H}-\mathrm{NMR},{ }^{13} \mathrm{C}-\mathrm{NMR},{ }^{11} \mathrm{~B}-\mathrm{NMR}$, FT-IR spectroscopy, and electrospray ionization mass spectrometry (ESI-MS). 3-Benzyl-imidazolium-1-yl)trihydridoborate, $\left(\mathrm{HIm}^{\mathrm{Bn}}\right) \mathrm{BH}_{3}$, and (3-mesityl-imidazolium-1-yl)trihydridoborate, $\left(\mathrm{HIm}^{\mathrm{Mes}}\right) \mathrm{BH}_{3}$, were also characterized by $\mathrm{X}$-ray crystallography. The reactivity of these new compounds as carbene precursors in an effort to obtain borate-NHC complexes was investigated and a new carbene-borate adduct (which dimerizes) was obtained via a microwave-assisted procedure.
\end{abstract}

Keywords: $N$-heterocyclic carbenes; imidazole; spectroscopy; X-ray

\section{Introduction}

$\mathrm{N}$-heterocyclic carbenes (NHCs) [1-3] are an extremely useful and versatile class of ligands [4-10] with donor properties similar to phosphanes [11-14]. By tuning the steric and electronic properties around the carbene center, several carbenes featuring various $\sigma$-donating and $\pi$-accepting properties have been developed to date [15-17]. Their chemical versatility not only implies a wide variety of structural diversity and coordination modes, but also a capability to form stable complexes with a large number of transition metals with different oxidation states [6,7,18-20] and labile ligands [21-26]. Metal-NHCs complexes gained considerable interest in recent years because of their application in material chemistry [27], in catalysis [19,28-37], in carbene transfer reactions [38,39], and in medicinal inorganic chemistry [40-49].

In the last thirty years, several carbenes based on the imidazol-2-ylidene (Scheme 1a) as well as the imidazolin-2-ylidene [50] and the chain-like carbene compound have been reported [51]. Such NHCs compounds have in common the presence of only organic substituents attached to the nitrogen atoms, whereas carbenes with other main-group elements as substituents (Scheme 1b) are scarce [52-56]. Substitution of one of the groups attached to nitrogen by a borane would result in the generation of

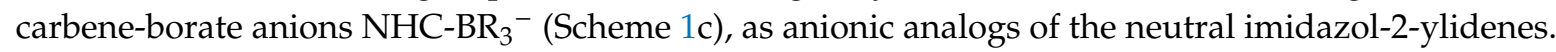


To the best of our knowledge, only few examples of monoanionic carbenes such as the on in Scheme 1c have been published as yet [53,57-63].<smiles></smiles>

$\mathrm{R}, \mathrm{R}^{\prime}=$ alkyl or aryl

(a)<smiles>[R]N1C=CN([X])C1</smiles>

$\mathrm{R}=$ alkyl or aryl $X=$ main-group element

(b)<smiles>[R3]N1C=CN([R])C1</smiles>

NHC-BR ${ }^{-}$

$\mathrm{R}=$ alkyl or aryl

(c)

Scheme 1. Structure of carbenes based on the imidazol-2-ylidene moieties: (a) with alkyl and aryl substituents; (b) with a main-group element substituent; (c) with a borate moiety substituent.

In 1998 and 2002, Siebert and co-workers reported that deprotonation of imidazole-borane complexes or imidazolium-borate species (Scheme 2a) with BuLi leads to the formation of the carbene-borate anions $\mathrm{NHC}_{-} \mathrm{BH}_{3}{ }^{-}[59,64]$. These kinds of nucleophilic carbenes allowed the formation of neutral manganese complexes and anionic iron compounds by reactions with $\mathrm{BrMn}(\mathrm{CO})_{5}$ and $\mathrm{Fe}(\mathrm{CO})_{5}$, respectively [59]. The analogous reaction with $\left[\left(\mathrm{C}_{7} \mathrm{H}_{11}\right) \mathrm{Fe}(\mathrm{CO})_{2} \mathrm{Br}\right], \mathrm{Cp}_{2} \mathrm{TiCl}_{1} \mathrm{VCl}_{3}$, and $\mathrm{ScCl}_{3}$ yielded the corresponding metal complexes [64]. Bis(imidazolyl) compounds with $\mathrm{BH}_{3}$ or $\mathrm{BEt}_{3}$ (Scheme $2 \mathrm{~b}$ ) and their behavior towards treatment with butyllithium to give dianionic chelating dicarbene-diborate ligands have also been reported [53]. Among them, the dianionic bis(imidazol-2-ylidene) species obtained from b2 (Scheme 2) reacted with $\mathrm{Cp}_{2} \mathrm{TiCl}_{2}$ and $\mathrm{Cp}_{2} \mathrm{ZrCl}_{2}$ allowing the formation of the corresponding carbene-borate complexes [53]. Isomerization to the 2-borate imidazole forms by 1,2-BR 3 migration [65], intramolecular addition/elimination or dimerization reactions may or may not occur on deprotonation [57-61,66]. For example, deprotonation of the triethylborane adduct (Scheme 2c) produced the isomerized $N$-heterocyclic carbene-borate species (Scheme 2d) [59]. Attempts to synthesize the carbene-borate anions by deprotonation of the parent imidazole (Scheme 2(e1,e2)) and benzimidazole (Scheme 2(e3)) adducts, have invariably resulted in the formation of isomers (Scheme 2f) $[57,67]$ by ring-closure due to a rapid intramolecular nucleophilic aromatic substitution. On the other hand, Contreras et al. $[60,66]$ reported the imidazaboles (Scheme 2(g1,g2)), by elimination of $\mathrm{H}_{2}$ from the ( $\mathrm{N}$-alkylimidazolium)borate species with iodine at $270{ }^{\circ} \mathrm{C}$. Okada et al. [61] reported the synthesis of analogous imidazaboles (Scheme 2(g3,g4)), from reaction of the parent $(N$-alkylimidazolium)borates with organolithium reagents. Recently, Chiu and coworkers [65] reported that dimerization of 2-borylimidazoles through B-N coordination yielded the head-to-tail dimers g5 and g6 (Scheme 2). Compound g7 is the only isolable product of the reaction of $\left[\mathrm{Ph}_{2} \mathrm{~B}\left(\mathrm{Im}^{\mathrm{t}} \mathrm{Bu}\right)_{2} \mathrm{Br}\right]$ and $\left[\mathrm{Ca}\left\{\mathrm{N}\left(\mathrm{SiMe}_{3}\right)_{2}\right\}_{2}(\mathrm{THF})_{2}\right]$ [68].

Functionalized imidazole-based NHCs have attracted special interest because they can be utilized to tune the environment and properties at the coordinated metal [4,69]. Whereas there are many studies describing the coordination of chelate and pincer $N$-heterocyclic carbene ligands, the use of anionic NHC-borates is still scarce [52,63]. Recently, significant research efforts have been devoted to the development of ionic liquids based on ( $N$-alkylimidazolium)borate as new potential hypergolic fuels owing to their excellent physiochemical properties including and unique hypergolic reactivity [70]. The first chelating tricarbene ligand with the topology of Trofimenko's tris(pyrazolyl)borates [71,72], tris(3-methylimidazolin-2-ylidene-1-yl)borate, in which the carbene units are connected via a BH group, was introduced in 1995 by Fehlhammer and co-workers [54] together with its hexacarbene iron(III) and cobalt(III) complexes [73,74]. The synthesis of monoanionic chelating dicarbene bis(imidazol-2-ylidene-1-yl)borates and their use as ligands in various homoleptic and heteroleptic metal complexes has been described [75,76] and recently reviewed [15,52]. 
<smiles></smiles>

a1: $\mathrm{R}=\mathrm{CH}_{3} ; \mathrm{R}^{\prime}=\mathrm{CH}_{3}$ a2: $\mathrm{R}=\mathrm{CH}_{3} ; \mathrm{R}^{\prime}=\mathrm{H}$ a3: $\mathrm{R}=\mathrm{CH}_{3} ; \mathrm{R}^{\prime}=\mathrm{C}_{2} \mathrm{H}_{2}$ a4: $\mathrm{R}=\mathrm{C}_{4} \mathrm{H}_{9} ; \mathrm{R}^{\prime}=\mathrm{H}$

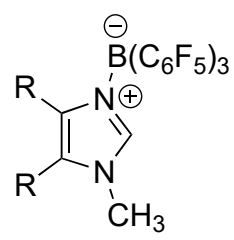

e1: $\mathrm{R}=\mathrm{H}$

e2: $\mathrm{R}=\mathrm{CH}_{3}$<smiles>[R]Cc1c([R])c([R3])n(Cn2c[n+]([B])c([R])c2[R])c1[R]</smiles>

b1: $\mathrm{R}=\mathrm{H}$; R' = H

b2: $\mathrm{R}=\mathrm{H} ; \mathrm{R}^{\prime}=\mathrm{CH}_{3}$

b3: $\mathrm{R}=\mathrm{Et} ; \mathrm{R}^{\prime}=\mathrm{H}$<smiles>CC[B-](C)[N+]1CN(C)C(C)=C1C</smiles>

c<smiles>C[B-]c1nc(C)c(C)n1C</smiles>

d<smiles></smiles>

e3<smiles>[R]C([R])=C1B2c3c(F)c(F)c(F)c(F)c3-c3c([R])c([R])n(C)c3N1[B-]2(C(F)(F)F)C(F)(F)F</smiles>

f1: $\mathrm{R}=\mathrm{H}$

f2: $\mathrm{R}=\mathrm{CH}_{3}$<smiles>Cn1c(F)c(F)c2c1N(c1ccccc1)[B-](C(F)(F)F)(C(F)(F)F)c1c(F)c(F)c(F)c(F)c1-2</smiles>

f3<smiles></smiles>

g1: $\mathrm{R}^{\prime}=\mathrm{H}, \mathrm{R}=\mathrm{CH}_{3}$

g2: $\mathrm{R}^{\prime}=\mathrm{H}, \mathrm{R}=\mathrm{CH}_{2} \mathrm{C}_{6} \mathrm{H}_{5}$

g3: $\mathrm{R}^{\prime}=$ Mesityl, $\mathrm{R}=\mathrm{CH}_{3}$

g4: $\mathrm{R}^{\prime}=$ Mesityl, $\mathrm{R}=\mathrm{C}_{6} \mathrm{H}_{5}$

g5: $R^{\prime}=$ Mesityl, $R={ }^{n} \mathrm{Bu}$

g6: $R^{\prime}=2,6-X y l, R={ }^{n} B u$

g7: $\mathrm{R}^{\prime}=\mathrm{C}_{6} \mathrm{H}_{5}, \mathrm{R}={ }^{\mathrm{t}} \mathrm{Bu}$

Scheme 2. Structure of: (a) imidazolium trihydridoborate species; (b) bis(imidazolium)borate species; (c) imidazolium triethylborate species; (d) 2-substituted imidazolylborate species; (e) imidazolium and benzimidazolium triarylborate species; (f) ring-closed imidazolium and benzimidazolium triarylborate species; (g) imidazaboles.

In the last years, we developed several classes of coinage metal NHCs complexes obtained from the chelating precursors $\left[\mathrm{HB}(\mathrm{RImH})_{3}\right] \mathrm{Br}_{2}\left(\mathrm{R}=\right.$ Benzyl, Mesityl and t-Butyl) [77], $\left[\mathrm{H}_{2} \mathrm{~B}\left(\mathrm{HTz}^{\mathrm{Bn}}\right)_{2}\right] \mathrm{Br}$ [78], $\mathrm{H}_{2} \mathrm{C}\left(\mathrm{HTz}^{\mathrm{R}}\right)_{2}$, and $\mathrm{H}_{2} \mathrm{C}\left(\mathrm{HIm}^{\mathrm{R}}\right)_{2}\left(\mathrm{HTz}=1,2\right.$,4-triazole; $\mathrm{HIm}=$ imidazole; $\mathrm{R}=\left(\mathrm{CH}_{2}\right)_{3} \mathrm{SO}_{3}{ }^{-}$or $\left.\left(\mathrm{CH}_{2}\right)_{2} \mathrm{COO}^{-}\right)$[79]. Recently, we have focused the research work on the development of new group 11 metal-NHCs complexes obtained from the water-soluble precursors $\mathrm{HIm}{ }^{1 \mathrm{R}, 3 \mathrm{R}} \mathrm{Cl}\left(\mathrm{R}=\mathrm{COOCH}_{3}\right.$, $\mathrm{COOCH}_{2} \mathrm{CH}_{3}$, or $\left.\mathrm{CON}\left(\mathrm{CH}_{2} \mathrm{CH}_{3}\right)_{2}\right)[80,81]$ or the zwitterionic water-soluble precursor $\mathrm{NaHIm}^{1 \mathrm{R}, 3 \mathrm{R}}$ $\left(\mathrm{R}=\left(\mathrm{CH}_{2}\right)_{3} \mathrm{SO}_{3}{ }^{-}\right)[82]$.

Despite the impressive chemistry based on parent poly(azolyl)borate, the analogous mono(azolyl)borate have received very little attention in recent years $[83,84]$. Recently, we prepared trihydro(pyrazolyl)borates such as $\mathrm{Na}\left[\mathrm{H}_{3} \mathrm{~B}\left(5-\left(\mathrm{CF}_{3}\right) \mathrm{pz}\right)\right]$ and $\mathrm{Na}\left[\mathrm{H}_{3} \mathrm{~B}\left(3-\left(\mathrm{NO}_{2}\right) \mathrm{pz}\right)\right]$ and related copper(I) and silver(I) phosphane complexes [85,86].

Here, we present the synthesis of ( $N$-(alkyl/aryl)imidazolium)borate-based systems (Scheme 3) and their reactivity as carbene precursors in the effort to obtain borate-NHCs silver(I) complexes. 
<smiles></smiles>
1: $R=$ benzyl
2: $R=$ mesityl
3: $\mathrm{R}=\mathrm{CH}_{3}$
4: $\mathrm{R}=$ benzyl<smiles></smiles>

Scheme 3. Chemical structures of ( $N$-(alkyl/aryl)imidazolium)borates 1-4.

\section{Result and Discussion}

\section{Synthesis and Characterization}

The $N$-(alkyl/aril)imidazolium-borate adducts $\mathbf{1 - 4}$ were synthesized in one step by two different routes (Scheme 4).
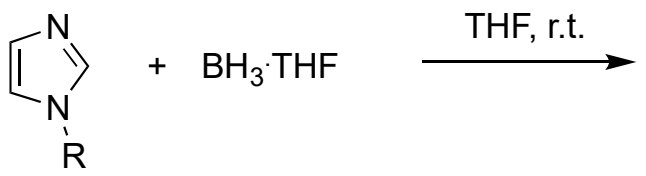

(a)<smiles>[R]n1ccnc1[NH2+][SnH3]</smiles>

(b)<smiles>[R]n1cc[n+]([BH3-])c1</smiles>

1: $R=$ benzyl

2: $R=$ mesityl<smiles></smiles>

3: $\mathrm{R}=\mathrm{CH}_{3}$

4: $\mathrm{R}=$ benzyl

Scheme 4. Synthesis of: (a) imidazolium trihydridoborates 1 and 2; (b) imidazolium triphenyborates 3 and 4.

The addition of one equivalent of $\mathrm{BH}_{3} \bullet \mathrm{THF}$ to a solution of $N$-benzylimidazole or $\mathrm{N}$-mesitylimidazole at room temperature yields the colorless imidazolium-borate adducts $\mathbf{1}$ or $\mathbf{2}$, respectively, in nearly quantitative yields (Scheme 4a). By dissolving the crude ligands $\mathbf{1}$ and $\mathbf{2}$ in $\mathrm{CHCl}_{3}$ and $\mathrm{CHCl}_{3} / \mathrm{THF}$ solution, respectively, single crystals suitable for X-ray diffraction analysis were obtained.

Compounds 3 and 4 were prepared by addition of $\mathrm{NH}_{4} \mathrm{BPh}_{4}$ to an acetonitrile solution of methylimidazole or benzylimidazole under reflux conditions. It is known that under acidic conditions 
the tetraphenylborate anion has limited stability producing triphenylboranes [87], and when heated with alkylammonium salts can lose a phenyl ring to form a B-N bond with the ammonium compound [88]. This kind of displacement was observed in our studies: the loss of a phenyl ring and the formation of imidazolium-triphenylborate species occurred in good yields, volatile benzene and ammonia being also produced. Compound 3 was previously obtained as a crystalline byproduct of the reaction mixture of $\left[\mathrm{ReO}_{2}(1-\mathrm{MeIm})_{4}\right]^{+}$complex and $\mathrm{NaBPh}_{4}$ in acidic conditions [89].

Derivatives $\mathbf{1}$ and $\mathbf{2}$ are white and brownish solids, respectively, both soluble in $\mathrm{CH}_{3} \mathrm{OH}, \mathrm{CHCl}_{3}$, $\mathrm{CH}_{2} \mathrm{Cl}_{2}$, THF, DMSO, and acetone. Derivatives 3 and 4 are white solids, both soluble in THF, $\mathrm{CH}_{2} \mathrm{Cl}_{2}$, $\mathrm{CHCl}_{3}, \mathrm{CH}_{3} \mathrm{CN}$, DMSO, and acetone.

The authenticity of compounds $\mathbf{1}-\mathbf{4}$ was confirmed by $\mathrm{CHN}$ analysis, ${ }^{1} \mathrm{H}-\mathrm{NMR},{ }^{13} \mathrm{C}-\mathrm{NMR}$, ${ }^{11} \mathrm{~B}-\mathrm{NMR}, \mathrm{FT}-\mathrm{IR}$ spectroscopy, and electrospray ionization mass spectrometry (ESI-MS). Compounds 1 and 2 were also characterized by $\mathrm{X}$-ray crystallography.

The $\left(\mathrm{HIm}^{\mathrm{Bn}}\right) \mathrm{BH}_{3}(\mathbf{1})$ crystallizes in the Orthorhombic $\mathrm{P} 2{ }_{1} 2_{1} 2_{1}$ space group. The molecular structure is illustrated in Figure 1. It is monomeric in the solid state and C1-N1 distance is slightly longer than the C1-N2 distance.

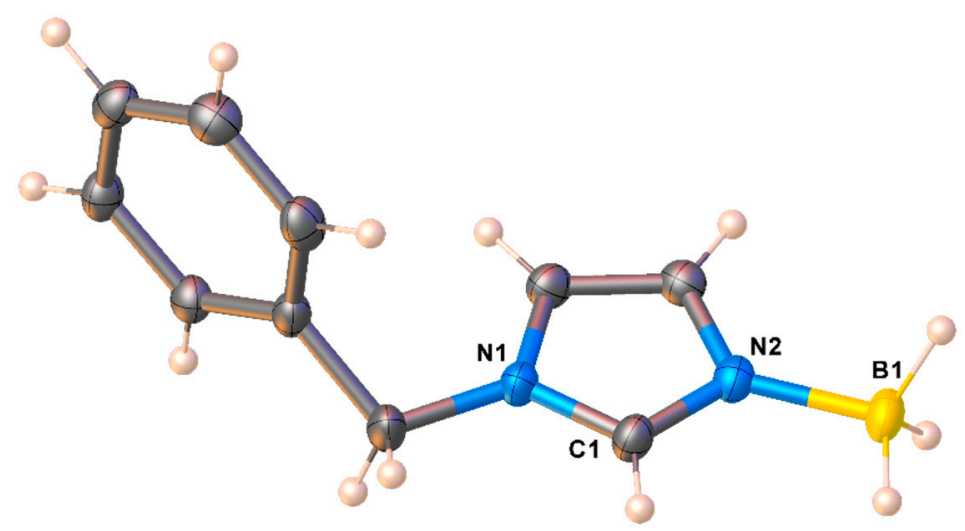

Figure 1. Molecular structure of $\left(\mathrm{HIm}^{\mathrm{Bn}}\right) \mathrm{BH}_{3}(\mathbf{1})$. Selected bond distances $(\AA)$ and angles $\left({ }^{\circ}\right)$ : N1-C1 1.343(2), N2-C1 1.323(2), N2-B1 1.587(2), N1-C4 1.474(2), N1-C1-N2 110.29(14), C1-N2-B1 126.58(14).

The molecular structure of $\left(\mathrm{HIm}^{\mathrm{Mes}}\right) \mathrm{BH}_{3}(2)$ is shown in Figure 2. It crystallizes in the Monoclinic $\mathrm{P} 21 / n$ space group with two chemically similar but crystallographically different molecules in the asymmetric unit. Structural features of $\mathbf{2}$ are similar to those observed for $\mathbf{1}$.

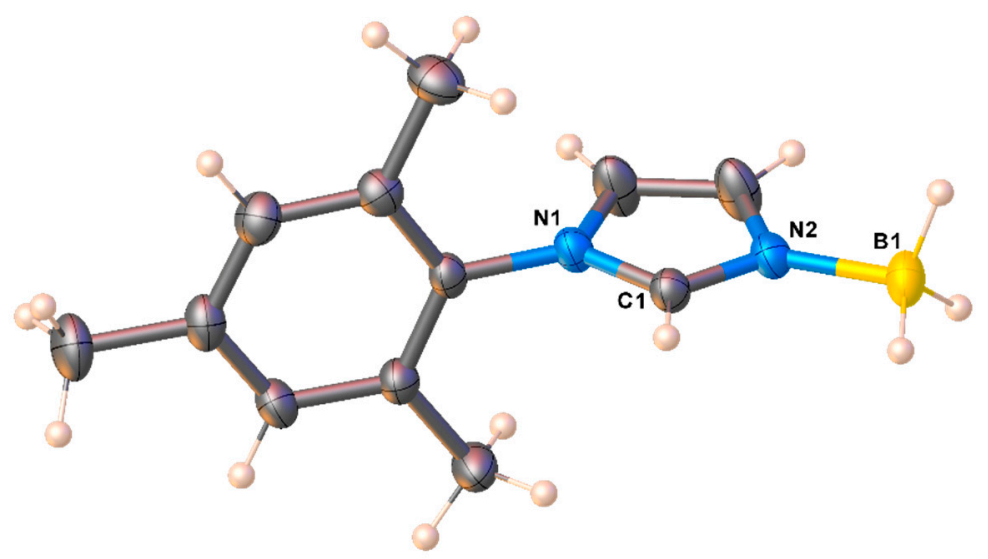

Figure 2. Molecular structure of $\left(\mathrm{HIm}^{\mathrm{Mes}}\right) \mathrm{BH}_{3}$ (2). There are two chemical similar but crystallographically different molecules of $\left(\mathrm{HIm}^{\mathrm{Mes}}\right) \mathrm{BH}_{3}$ in the asymmetric unit but only one is shown here. Selected bond distances $(\AA)$ and angles $\left(^{\circ}\right)$ : N1-C1 1.3442(14), N2-C1 1.3207(14), N2-B1 1.5836(16), N1-C4 1.4465(14), N1-C1-N2 110.36(10), C1-N2-B1 127.91(10). 
The FT-IR spectra of Compounds 1-4 showed weak absorptions in the range $3010-3177 \mathrm{~cm}^{-1}$, due to the azolyl ring $\mathrm{C}-\mathrm{H}$ stretching and the presence of the $\mathrm{BH}_{3}$ moiety in Compounds $\mathbf{1}$ and 2 was detected by intense absorptions at 2255-2374 $\mathrm{cm}^{-1}$.

The ${ }^{1} \mathrm{H}$ - and ${ }^{13} \mathrm{C}$-NMR spectra of 1 and 2 were recorded in $\mathrm{CDCl}_{3}$ and $\mathrm{CD}_{3} \mathrm{OD}$, while the spectra of 3 and $\mathbf{4}$ were recorded in DMSO solution. Compounds 1-4 showed a single set of resonances for the imidazolium rings. The ${ }^{1} \mathrm{H}$ NMR spectra of Compounds $\mathbf{1}$ and $\mathbf{2}$ at the $2-\mathrm{CH}$ position does not show any reduced intensity after two days in $\mathrm{CD}_{3} \mathrm{OD}$ solution at room temperature, suggesting the absence of fast H-D exchange and therefore lack of deuteration at this position.

The ${ }^{11} \mathrm{~B}-\mathrm{NMR}$ spectra showed a quartet at $\delta-19.38$ and $-19.21 \mathrm{ppm}$ for Compounds $\mathbf{1}$ and 2, respectively, in $\mathrm{CDCl}_{3}$ solution, indicating a coordination of the imidazole rings at the $\mathrm{BH}_{3}$ group [62,90]. The single broad ${ }^{11} \mathrm{~B}$ resonances observed at $\delta-6.52 \mathrm{ppm}$ for Compound 3 and at $\delta-6.37$ ppm for Compound 4 , in $\left(\mathrm{CD}_{3}\right)_{2} \mathrm{CO}$ and $\mathrm{CDCl}_{3}$ solutions, respectively, are indicative of a four-coordinate boron center; they are in the range observed for analogously triphenylborate species [91], being considerably shifted in comparison with the triphenylborane one, which is observed at $\delta-60.2 \mathrm{ppm}$ [92].

In the ESI(+)-MS spectra of $\mathbf{1}$ and $\mathbf{2}$ we observed peaks at $m / z 195$ and 223, due to the molecular specie $\left[\left(\mathrm{HIm}^{\mathrm{Bn}}\right) \mathrm{BH}_{3}+\mathrm{Na}\right]^{+}$and $\left[\left(\mathrm{HIm}^{\mathrm{Mes}}\right) \mathrm{BH}_{3}+\mathrm{Na}\right]^{+}$, respectively. In addition the ESI $(+) \mathrm{MS}$ spectra displayed peaks due to the fragmentation species $\left[\mathrm{HIm}^{\mathrm{R}}+\mathrm{H}\right]^{+}$and to the aggregates $\left[\left(\mathrm{HIm}^{\mathrm{R}}\right)_{2} \mathrm{BH}_{2}\right]^{+}$ $(\mathrm{R}=\mathrm{Bn}$ or Mes). Analogously, the ESI(+)-MS spectra of Compounds 3 and 4 were dominated by the peaks at $m / z 83$ and 159 due to the $\left[\mathrm{HIm}{ }^{\mathrm{CH} 3}+\mathrm{H}^{+}\right.$and $\left[\mathrm{HIm}^{\mathrm{Bn}}+\mathrm{H}\right]^{+}$, respectively, along with a fragment at $m / z 247\left(\left[\left(\mathrm{HIm}^{\mathrm{CH} 3}\right) \mathrm{BPh}_{2}\right]^{+}, 25 \%\right)$ and an aggregate at $481\left(\left[\left(\mathrm{Im}^{\mathrm{Bn}}\right)_{2} \mathrm{BPh}_{2}\right]^{+}, 45 \%\right)$, in 3 and 4 respectively.

Our aim was to synthesize new $N$-(alkyl/aryl)imidazolium-borates and study their reactivity and investigate their reactivity as carbene precursors in an effort to obtain borate-NHCs silver(I) complexes. However, treatment of Compounds 1-4 with ${ }^{\mathrm{n}} \mathrm{BuLi}$ to yield the imidazol-2-ylidenes always led to decomposition species. Further direct reactions of 1-4 with $\mathrm{Ag}_{2} \mathrm{O}$, in different reaction conditions (r.t. or reflux; reaction times $=5,24,48$, and $120 \mathrm{~h}$; solvent $=\mathrm{THF}, \mathrm{CH}_{2} \mathrm{Cl}_{2}, \mathrm{CH}_{3} \mathrm{OH}$, and $\mathrm{CH}_{3} \mathrm{CN}$ ), or with silver acetate (in $\mathrm{CH}_{3} \mathrm{OH}$ or $\mathrm{CH}_{3} \mathrm{CN}$ ) to give silver carbene complexes were unsuccessful: only mixtures of unreacted or decomposition products were detected. The only partially isolable product of the reaction of 4 and $\mathrm{Ag}_{2} \mathrm{O}$ in $\mathrm{CH}_{3} \mathrm{CN}$ was the imidazabole species 5. After these efforts, we found that the direct synthesis of imidazaboles [60,61,66] could be achieved by using microwave-assisted procedure [93], following a pre-set heating ramp of $1 \mathrm{~h}$ up to $80^{\circ} \mathrm{C}$, in technical-grade $\mathrm{CH}_{3} \mathrm{CN}$ and in the presence of $\mathrm{Ag}_{2} \mathrm{O}$ (Scheme 5). Unfortunately, this methodology was only successful for Compound 5, and mixtures of products were obtained by using microwave-assisted procedure employing Compounds 1-3 as starting materials.
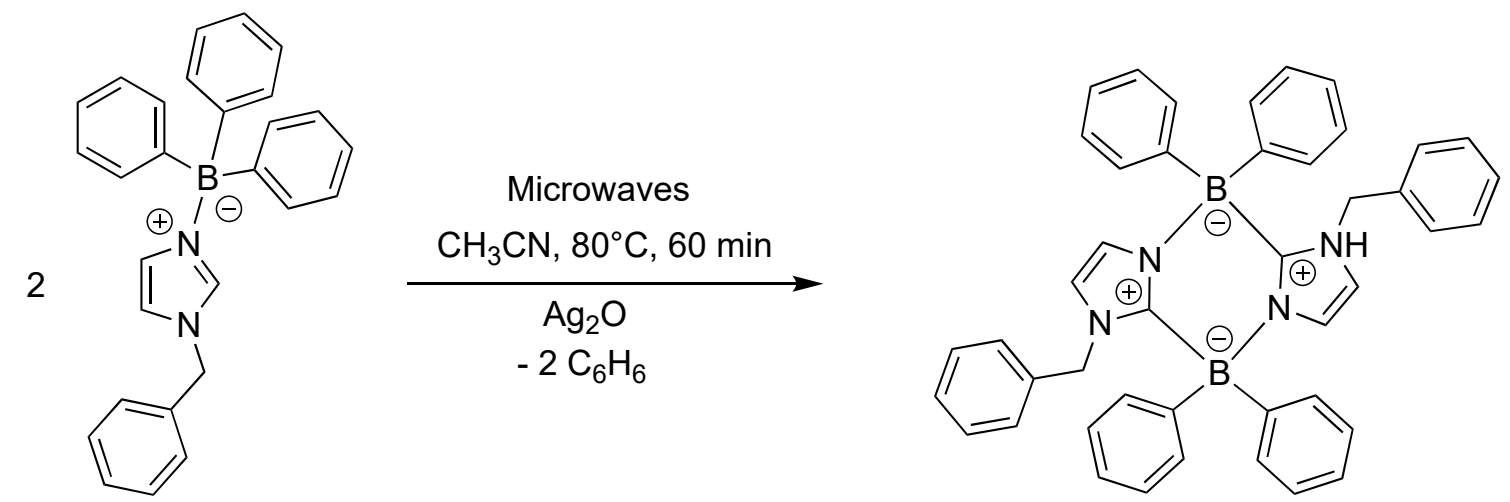

Scheme 5. Microwave-assisted synthesis of Compound 5.

Compound 5 is an oil soluble in $\mathrm{CH}_{3} \mathrm{OH}, \mathrm{CH}_{3} \mathrm{CN}$ and DMSO. Its formation can be explained by the abstraction of proton at 2-position of the imidazolium-triphenylborate and the successive bimolecular condensation of the produced anions with elimination of two benzene molecules (Scheme 5) [65]. 
Compound 5 has a framework of 1,4-diazonia-2,5-diboratacyclohexa-3,6-diene, which can also be regarded as an intramolecular carbene-borate adduct $[59,60]$.

NMR spectra showed significant changes going from Compound 4 to the corresponding imidazabole species 5. In particular, the ${ }^{1} \mathrm{H}-\mathrm{NMR}$ spectrum of 5 recorded in deuterated DMSO showed the disappearance of the diagnostic 2- $\mathrm{CH}$ imidazolium signal of 4 at $8.37 \mathrm{ppm}$ upon cyclization. Analogously, in the ${ }^{13} \mathrm{C}$-NMR spectrum, the $2-\mathrm{CH}$ imidazolium signal of 4 at $136.33 \mathrm{ppm}$ was no longer observed in the spectrum of 5 that instead showed a new, albeit poorly intense, 2-C signal at $159.18 \mathrm{ppm}$ indicative of the carbene-borate formation [94]. The remaining ${ }^{13} \mathrm{C}-\mathrm{NMR}$ data are very similar to those of 4 . The ${ }^{11} \mathrm{~B}-\mathrm{NMR}$ spectrum contains a singlet at $\delta 1.43$. The decreased ${ }^{11} \mathrm{~B}-\mathrm{NMR}$ nuclear shielding in 5 as compared to $4\left(\delta^{11} \mathrm{~B}-6.37\right)$ points towards lower delocalization of the positive charge in the imidazabole system [95].

Isomerization to the 2-borate imidazole forms by 1,2- $\mathrm{BR}_{3}$ migration [65], intramolecular addition/elimination or dimerization reactions may occur on deprotonation [57-61,66], presumably involving intermediates such as in Scheme 6A,B.

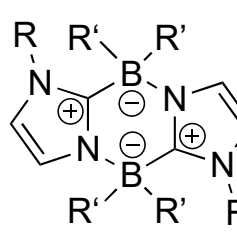

C<smiles></smiles>

A<smiles>[R18]c1nccn1[R]</smiles>

B

Scheme 6. Rearrangement species $(\mathbf{B}, \mathbf{C})$ by isomerization or dimerization of the NHC-borate form (A).

DFT studies by Vagedes et al. [57] suggested that direct interconversion of such anions by 1,2-migration is very unlikely. The borate substituent thermodynamically prefers to be bound to C-2 of the anionic heterocyclic moiety. Presumably, the Lewis acidic borane compensates the negative charge much more efficiently when bound to the carbon atom than when bound to the nitrogen atom, but their interconversion was precluded by a very high barrier of the respective 1,2-BR 3 shift [57]. In particular, for Compound 5, the probably initially generated "anionic Arduengo carbene" product A is proved unstable under the reaction conditions and it must be assumed that the rearrangement, experimentally observed to yield species $C$, is likely to have proceeded intermolecularly by two successive nucleophilic substitutions or by radical pathway as recently proposed by Chiu et al. [65].

As demonstrated in the $\mathrm{BR}_{3}$-functionalized $\mathrm{NHC}$, the incorporation of anionic borate functionality enhances the donating ability of NHC $[96,97]$. However, we must conclude that the $\mathrm{N}$-borato carbene anion A could exhibit its characteristic NHC chemistry when prepared or generated under conditions precluding intermolecular rearrangement pathways to their thermodynamically favored C(2)-borated imidazole isomers or head-to-tail imidazabole dimers.

\section{Experimental Section}

\subsection{Materials and General Methods}

All syntheses and handling were carried out under an atmosphere of dry oxygen-free dinitrogen, using standard Schlenk techniques or a glove box. Glassware was dried with a heat-gun under high vacuum. Solvents were purchased from commercial sources and purified by conventional methods prior to use. Elemental analyses $(\mathrm{C}, \mathrm{H}, \mathrm{N}$, and S) were performed with a Fisons Instruments EA-1108 CHNS-O Elemental Analyzer (Thermo Fisher Scientific Inc., Waltham, MA, USA). Melting points were taken on an SMP3 Stuart Scientific Instrument (Bibby Sterilin Ltd., London, UK). IR spectra were recorded from 4000 to $400 \mathrm{~cm}^{-1}$ on a PerkinElmer Frontier FT-IR instrument (Perkin Elmer Inc., Waltham, MA, USA), equipped with single reflection universal diamond ATR top-plate. IR annotations used were as follows: $\mathrm{br}=$ broad, $\mathrm{m}=$ medium, $\mathrm{mbr}=$ medium broad, $\mathrm{s}=$ strong, $\mathrm{sbr}=$ strong broad, 
$\mathrm{sh}=$ shoulder, $\mathrm{vs}=$ very strong, $\mathrm{w}=$ weak, wbr $=$ weak broad. ${ }^{1} \mathrm{H}-,{ }^{13} \mathrm{C}-$, and ${ }^{11} \mathrm{~B}-\mathrm{NMR}$ spectra were recorded with an Oxford AS400 Varian spectrometer $\left(400.4 \mathrm{MHz}\right.$ for ${ }^{1} \mathrm{H}, 100.1 \mathrm{MHz}$ for ${ }^{13} \mathrm{C}$, and $128.4 \mathrm{MHz}$ for ${ }^{11} \mathrm{~B}$ ) (Oxford Instruments, MA, USA) or with a 500 Bruker Ascend $(500.1 \mathrm{MHz}$ for ${ }^{1} \mathrm{H}, 125 \mathrm{MHz}$ for ${ }^{13} \mathrm{C}$, and $160.5 \mathrm{MHz}$ for ${ }^{11} \mathrm{~B}$ ) (Bruker BioSpin Corporation, 15 Fortune Drive, Billerica, MA, USA). Referencing was relative to tetramethylsilane (TMS) $\left({ }^{1} \mathrm{H}\right.$ and $\left.{ }^{13} \mathrm{C}\right)$ and $\mathrm{BF}_{3}$. $\mathrm{Et}_{2} \mathrm{O}$ $\left({ }^{11} \mathrm{~B}\right)$. NMR annotations used were as follows: $\mathrm{br}=$ broad; $\mathrm{d}=$ doublet, $\mathrm{m}=$ multiplet, $\mathrm{s}=$ singlet. Syntheses under microwave irradiation were performed by means of a Flexible Microwave Platform FlexSynth Milestone apparatus (Milestone Srl, Via Fatebenefratelli, Sorisole (BG), Italy). The reactions were performed in a 100-mL PTFE vessel, sealed using a Teflon crimp top. Electrospray mass spectra (ESI-MS) were obtained in positive-(ESI(+)MS) or negative-ion (ESI(-)MS) mode on an Agilent Technologies Series 1100 LC/MSD Mass Spectrometer (Agilent Technologies Inc, Santa Clara, CA, USA), using a methanol or acetonitrile mobile phase. The compounds were added to reagent grade methanol to give approximately $0.1 \mathrm{mM}$ solutions, injected $(1 \mu \mathrm{L})$ into the spectrometer via a Hewlett Packard 1090 Series II UV-Visible HPLC system (Agilent Technologies Inc, Santa Clara, CA, USA) fitted with an autosampler. The pump delivered the solutions to the mass spectrometer source at a flow rate of $300 \mathrm{~mL} \mathrm{~min}^{-1}$, and nitrogen was employed both as a drying and nebulizing gas. Capillary voltages were typically 4000 and $3500 \mathrm{~V}$ for the ESI(+)MS and ESI(-)MS modes, respectively. Confirmation of all major species in this ESI-MS study was supported by comparison of the observed and predicted isotope distribution patterns, the latter calculated using the IsoPro 3.1 computer program (T-Tech Inc., Norcross, GA, USA). 1-Benzylimidazole, 1-methylimidazole, $\mathrm{BH}_{3} \bullet \mathrm{THF}$ complex, ammonium tetraphenylborate, and silver oxide were purchased from Sigma-Aldrich (Merck Life Science S.r.l., Via Monte Rosa, Milano, Italy). The 1-mesitylimidazole was synthesized in accordance with the literature method [98].

Caution! The materials used and synthesized in this study are energetic. They should be handled in quantities not exceeding the millimolar scale. Manipulations should be carried out behind blast shields and with adequate personal safety gear.

\subsubsection{Synthesis of $\left(\mathrm{HIm}^{\mathrm{Bn}}\right) \mathrm{BH}_{3}(\mathbf{1})$}

1-Benzylimidazole $(1.840 \mathrm{~g}, 11.631 \mathrm{mmol})$ was dissolved in dry THF $(50 \mathrm{~mL})$ under $\mathrm{N}_{2}$ atmosphere and $\mathrm{BH}_{3} \bullet \mathrm{THF}$ complex $(12.0 \mathrm{~mL}, 1 \mathrm{M})$ was added drop by drop. The reaction mixture was stirred at room temperature for $24 \mathrm{~h}$. Then, the volatiles were removed under reduced pressure to give a colorless oil. It was re-crystallized by $\mathrm{CHCl}_{3} /$ diethyl ether/n-hexane $(1 / 3 / 3)$ solution to obtain a white precipitate; it was filtered, washed with diethyl ether, and dried under reduced pressure to give $\mathbf{1}$ in $80 \%$ yield $(1.601 \mathrm{~g})$. Single crystals of 1 suitable for $X$-ray analysis were obtained by slow evaporation of a $\mathrm{CHCl}_{3}$ solution of 1 . Melting point: $92-94{ }^{\circ} \mathrm{C}$. IR $\left(\mathrm{cm}^{-1}\right): 3159 \mathrm{w}, 3135 \mathrm{~m}, 3061 \mathrm{w}, 3038 \mathrm{w}$ (C-H); 2352m, 2297m, 2255m (B-H); 1540m, 1533m (C=C/C=N). ${ }^{1} \mathrm{H}-\mathrm{NMR}\left(\mathrm{CDCl}_{3}, 293 \mathrm{~K}\right): \delta 2.2$ (br, $\left.3 \mathrm{H}, \mathrm{BH}_{3}\right), 5.13\left(\mathrm{~s}, 2 \mathrm{H}, \mathrm{CH}_{2} \mathrm{Ph}\right), 6.91(\mathrm{~s}, 1 \mathrm{H}, 4-\mathrm{CH}$ or $5-\mathrm{CH}), 7.14(\mathrm{~s}, 1 \mathrm{H}, 4-\mathrm{CH}$ or 5-CH), 7.23-7.44 (m, $\left.5 \mathrm{H}, \mathrm{C}_{6} \mathrm{H}_{5}\right), 7.79(\mathrm{~s}, 1 \mathrm{H}, 2-\mathrm{CH}) .{ }^{1} \mathrm{H}-\mathrm{NMR}\left(\mathrm{CD}_{3} \mathrm{OD}, 293 \mathrm{~K}\right): \delta 2.2\left(\mathrm{qbr}, 3 \mathrm{H}, \mathrm{BH}_{3}\right), 5.24\left(\mathrm{~s}, 2 \mathrm{H}, \mathrm{CH}_{2} \mathrm{Ph}\right)$, 7,03 (s, 1H, 4-CH or 5-CH), $7.19(\mathrm{~s}, 1 \mathrm{H}, 4-\mathrm{CH}$ or $5-\mathrm{CH}), 7.26-7.43\left(\mathrm{~m}, 5 \mathrm{H}, \mathrm{C}_{6} \mathrm{H}_{5}\right), 8.13(\mathrm{~s}, 1 \mathrm{H}, 2-\mathrm{CH})$. ${ }^{13} \mathrm{C}\left\{{ }^{1} \mathrm{H}\right\}$-NMR $\left(\mathrm{CDCl}_{3}, 293 \mathrm{~K}\right): \delta 52.35\left(\mathrm{CH}_{2} \mathrm{Ph}\right), 119.94,127.98,128.21,129.33,129.47,133.46(\mathrm{CH})$, $136.33(2-\mathrm{CH}) .{ }^{11} \mathrm{~B}\left\{{ }^{1} \mathrm{H}\right\}-\mathrm{NMR}\left(\mathrm{CDCl}_{3}, 293 \mathrm{~K}\right): \delta-19.38\left(\mathrm{~s}, \mathrm{BH}_{3}\right) .{ }^{11} \mathrm{~B}-\mathrm{NMR}\left(\mathrm{CDCl}_{3}, 293 \mathrm{~K}\right): \delta-19.38(\mathrm{q}$, $\mathrm{BH}_{3}, \mathrm{~J}_{\mathrm{B}-\mathrm{H}}=96 \mathrm{~Hz}$ ). ESI-MS (major positive-ions, $\left.\mathrm{CH}_{3} \mathrm{OH}\right), \mathrm{m} / z(\%): 159(40)\left[\mathrm{HIm}^{\mathrm{Bn}}+\mathrm{H}^{+}, 181(40)\right.$ $\left[\mathrm{HIm}^{\mathrm{Bn}}+\mathrm{Na}\right]^{+}, 195(90)\left[\left(\mathrm{HIm}^{\mathrm{Bn}}\right) \mathrm{BH}_{3}+\mathrm{Na}\right]^{+}, 329(100)\left[\left(\mathrm{HIm}^{\mathrm{Bn}}\right)_{2} \mathrm{BH}_{2}\right]^{+}$. Anal. Calcd. for $\mathrm{C}_{10} \mathrm{H}_{13} \mathrm{BN}_{2}$ : C 69.82, H 7.62, N 16.28\%. Found: C 69.52, H 7.30, N 15.91\%.

\subsubsection{Synthesis of $\left(\mathrm{HIm}^{\mathrm{Mes}}\right) \mathrm{BH}_{3}(2)$}

1-mesityl-imidazole $(0.930 \mathrm{~g}, 5.000 \mathrm{mmol})$ was dissolved in dry THF $(30 \mathrm{~mL})$ under $\mathrm{N}_{2}$ atmosphere and $\mathrm{BH}_{3} \bullet$ THF complex $(5.2 \mathrm{~mL}, 1 \mathrm{M})$ was added drop by drop. The reaction mixture was stirred at room temperature for $24 \mathrm{~h}$. Then, the volatiles were removed under reduced pressure to give a brown oil. It was re-crystallized by $\mathrm{CHCl}_{3} /$ diethyl ether/n-hexane (1/3/3) solution to obtain a brown precipitate; it was filtered, washed with diethyl ether, and dried under reduced pressure to give $\mathbf{1}$ in 
$68 \%$ yield $(0.680 \mathrm{~g})$. Single crystals of 2 suitable for $\mathrm{X}$-ray analysis were obtained by slow evaporation of a $\mathrm{CHCl}_{3} / \mathrm{THF}$ solution of 2 . Melting point: $109-111^{\circ} \mathrm{C}$. IR $\left(\mathrm{cm}^{-1}\right): 3177 \mathrm{w}, 3155 \mathrm{w}, 3132 \mathrm{w}, 3061 \mathrm{w}$, 3028w (C-H); 2374m, 2338m, 2323m, 2300m, 2259m (B-H); 1526s (C=C/C=N). ${ }^{1} \mathrm{H}-\mathrm{NMR}\left(\mathrm{CDCl}_{3}, 293 \mathrm{~K}\right)$ : $\delta 2.03\left(\mathrm{~s}, 6 \mathrm{H}, \mathrm{CH}_{3}{ }^{\mathrm{Mes}}\right), 2.3\left(\mathrm{br}, 3 \mathrm{H}, \mathrm{BH}_{3}\right), 2.37$ (s, 3H, $\left.\mathrm{CH}_{3}{ }^{\mathrm{Mes}}\right), 6.90(\mathrm{~s}, 1 \mathrm{H}, 4-\mathrm{CH}$ or 5-CH), $7.02(\mathrm{~s}$, $\left.2 \mathrm{H}, \mathrm{CH}^{\mathrm{Mes}}\right), 7.31$ (s, 1H, 4-CH or 5-CH), $7.75(\mathrm{~s}, 1 \mathrm{H}, 2-\mathrm{CH}) .{ }^{1} \mathrm{H}-\mathrm{NMR}\left(\mathrm{CD}_{3} \mathrm{OD}, 293 \mathrm{~K}\right): \delta 2.04(\mathrm{~s}, 6 \mathrm{H}$, $\left.\mathrm{CH}_{3}{ }^{\mathrm{Mes}}\right), 2.1$ (br, 3H, BH 3 ), 2.35 (s, 3H, $\left.\mathrm{CH}_{3}{ }^{\mathrm{Mes}}\right), 7.08$ (s, $\left.2 \mathrm{H}, \mathrm{CH}^{\mathrm{Mes}}\right), 7.23(\mathrm{~s}, 1 \mathrm{H}, 4-\mathrm{CH}$ or 5-CH), 7.25 (s, $1 \mathrm{H}, 4-\mathrm{CH}$ or $5-\mathrm{CH}), 8.14(\mathrm{~s}, 1 \mathrm{H}, 2-\mathrm{CH}) .{ }^{13} \mathrm{C}\left\{{ }^{1} \mathrm{H}\right\}-\mathrm{NMR}\left(\mathrm{CDCl}_{3}, 293 \mathrm{~K}\right): \delta 17.33,21.06\left(\mathrm{CH}_{3}{ }^{\mathrm{Mes}}\right), 121.25$, $128.12,129.49,131.71,134.86,136.85(\mathrm{CH}), 140.34(2-\mathrm{CH}) .{ }^{11} \mathrm{~B}-\mathrm{NMR}\left(\mathrm{CDCl}_{3}, 293 \mathrm{~K}\right): \delta-19.21\left(\mathrm{dbr}, \mathrm{BH}_{3}\right)$. ESI-MS (major positive-ions, $\left.\mathrm{CH}_{3} \mathrm{OH}\right), \mathrm{m} / z(\%): 187(15)\left[\mathrm{HIm}^{\mathrm{Mes}}+\mathrm{H}\right]^{+}, 223(55)\left[\left(\mathrm{HIm}^{\mathrm{Mes}}\right) \mathrm{BH}_{3}+\mathrm{Na}\right]^{+}$, 385 (100) $\left[\left(\mathrm{HIm}^{\mathrm{Mes}}\right)_{2} \mathrm{BH}_{2}\right]^{+}$. Anal. Calcd. for $\mathrm{C}_{12} \mathrm{H}_{17} \mathrm{BN}_{2}$ : C 72.03, H 8.56, N 14.00\%. Found: C 71.81, H 8.25, N $13.60 \%$.

3.1.3. Synthesis of $\left(\mathrm{HIm}^{\mathrm{CH} 3}\right) \mathrm{BPh}_{3}(3)$

A large excess of 1-methylimidazole $(0.603 \mathrm{~g}, 7.344 \mathrm{mmol})$ was dissolved in acetonitrile $\left(\mathrm{CH}_{3} \mathrm{CN}\right.$, $60 \mathrm{~mL})$. Then, ammonium tetraphenylborate $\left(\mathrm{NH}_{4} \mathrm{BPh}_{4}, 1.770 \mathrm{~g}, 5.248 \mathrm{mmol}\right)$ was added to the solution. A white precipitate was formed, but the solution became limpid after $1 \mathrm{~h}$. The reaction proceeded for $70 \mathrm{~h}$ at reflux under magnetic stirring. At the end, the solution was dried at reduced pressure, obtaining a white solid. $\mathrm{Et}_{2} \mathrm{O}$ was added to the round-bottom flask to purify the residue from the starting materials that did not react. The resulting suspension was filtered, dried under reduced pressure, and furthe purified with $\mathrm{CHCl}_{3}$ to precipitate the excess of $\mathrm{NH}_{4} \mathrm{BPh}_{4}$. The mixture was filtered and the mother liquors were dried at reduced pressure to give the white ligand $\left(\mathrm{HIm}^{\mathrm{CH} 3}\right) \mathrm{BPh}_{3}$ (3) in $76 \%$ yield (1.293 g). Melting point: $209-212{ }^{\circ} \mathrm{C}$. IR $\left(\mathrm{cm}^{-1}\right): 3158 \mathrm{w}, 3133 \mathrm{~m}, 3085 \mathrm{w}, 3064 \mathrm{~m}, 3054 \mathrm{mbr}$, $3010 \mathrm{mbr}(\mathrm{C}-\mathrm{H}) ; 1546 \mathrm{~m}, 1531 \mathrm{~m}, 1483 \mathrm{mbr}(\mathrm{C}=\mathrm{C} / \mathrm{C}=\mathrm{N}) .{ }^{1} \mathrm{H}-\mathrm{NMR}\left(\mathrm{DMSO}-d_{6}, 293 \mathrm{~K}\right): \delta 3.79\left(\mathrm{~s}, 3 \mathrm{H}, \mathrm{NCH}_{3}\right)$, $6.90(\mathrm{~d}, 1 \mathrm{H}, 4-\mathrm{CH}$ or $5-\mathrm{CH}), 7.03-7.15(\mathrm{~m}, 15 \mathrm{H}, \mathrm{CH}), 7.44(\mathrm{~d}, 1 \mathrm{H}, 4-\mathrm{CH}$ or $5-\mathrm{CH}), 8.09(\mathrm{~s}, 1 \mathrm{H}, 2-\mathrm{CH})$. $\left.{ }^{13} \mathrm{C}_{1}^{1} \mathrm{H}\right\}-\mathrm{NMR}$ (DMSO-d $\left.{ }_{6}, 293 \mathrm{~K}\right): \delta 35.13\left(\mathrm{NCH}_{3}\right), 122.34,124.85,126.42,127.02,134.49,138.58(\mathrm{CH})$. ${ }^{11} \mathrm{~B}-\mathrm{NMR}$ (Acetone- $\left.d_{6}, 293 \mathrm{~K}\right): \delta-6.52\left(\mathrm{~s}, \mathrm{BPh}_{3}\right)$. ESI-MS (major positive ions, $\mathrm{CH}_{3} \mathrm{CN}$ ), $\mathrm{m} / z(\%): 83(100)$ $\left[\mathrm{HIm}{ }^{\mathrm{CH} 3}+\mathrm{H}^{+}, 247(25)\left[\left(\mathrm{HIm}^{\mathrm{CH} 3}\right) \mathrm{BPh}_{2}\right]^{+}\right.$. Anal. Calcd. for $\mathrm{C}_{22} \mathrm{H}_{21} \mathrm{BN}_{2}: \mathrm{C} 81.50, \mathrm{H}$ 6.53, $\mathrm{N}$ 8.64. Found: C 81.14, H 6.56, N 8.38.

\subsubsection{Synthesis of $\left(\mathrm{HIm}^{\mathrm{Bn}}\right) \mathrm{BPh}_{3}(4)$}

A large excess of 1-benzylimidazole $(0.633 \mathrm{~g}, 4.000 \mathrm{mmol})$ was dissolved in $\mathrm{CH}_{3} \mathrm{CN}(60 \mathrm{~mL})$. Then, $\mathrm{NH}_{4} \mathrm{BPh}_{4}(0.961 \mathrm{~g}, 2.850 \mathrm{mmol})$ was added to the solution. A white precipitate was formed, but the solution became limpid after $1 \mathrm{~h}$. The reaction proceeded for $70 \mathrm{~h}$ at reflux under magnetic stirring. At the end, the solution was dried at reduced pressure, obtaining a white solid. $\mathrm{EtOH}$ was added to the round-bottom flask to purify the residue from the starting materials that did not react. The resulting suspension was filtered and dried at reduced pressure to give the white ligand $\left(\mathrm{HIm}^{\mathrm{Bn}}\right) \mathrm{BPh}_{3}(4)$ in $50 \%$ yield $(0.570 \mathrm{~g})$. Melting point: $175-178{ }^{\circ} \mathrm{C}$. IR $\left(\mathrm{cm}^{-1}\right): 3163 \mathrm{~m}, 3140 \mathrm{~m}, 3125 \mathrm{~m}, 3064 \mathrm{mbr}, 3023 \mathrm{~m}$ $(\mathrm{C}-\mathrm{H}) ; 1531 \mathrm{mbr}, 1506 \mathrm{~m}, 1489 \mathrm{mbr}(\mathrm{C}=\mathrm{C} / \mathrm{C}=\mathrm{N}) .{ }^{1} \mathrm{H}-\mathrm{NMR}$ (DMSO-d $\left.6,293 \mathrm{~K}\right): \delta 5.39\left(\mathrm{~s}, 2 \mathrm{H}, \mathrm{CH}_{2} \mathrm{Ph}\right)$, $6.91(\mathrm{~s}, 1 \mathrm{H}, 4-\mathrm{CH}$ or $5-\mathrm{CH}), 7.04-7.43\left(\mathrm{~m}, 20 \mathrm{H}, \mathrm{C}_{6} \mathrm{H}_{5}\right), 7.49(\mathrm{~s}, 1 \mathrm{H}, 4-\mathrm{CH}$ or $5-\mathrm{CH}), 8.37(\mathrm{~s}, 1 \mathrm{H}, 2-\mathrm{CH})$. ${ }^{13} \mathrm{C}\left\{{ }^{1} \mathrm{H}\right\}-\mathrm{NMR}$ (DMSO- $\left.d_{6}, 293 \mathrm{~K}\right): \delta 51.24\left(\mathrm{CH}_{2} \mathrm{Ph}\right), 121.25,124.90,127.23,128.21,129.33,129.47,133.46$ (CH), $136.33(2-\mathrm{CH}) .{ }^{11} \mathrm{~B}-\mathrm{NMR}\left(\mathrm{CDCl}_{3}, 293 \mathrm{~K}\right): \delta-6.37$ (s, $\left.\mathrm{BPh}_{3}\right)$. ESI-MS (major positive ions, $\mathrm{CH}_{3} \mathrm{CN}$ ), $m / z(\%): 91(80)\left[\mathrm{C}_{7} \mathrm{H}_{7}\right]^{+}, 159(100)\left[\mathrm{HIm}^{\mathrm{Bn}}+\mathrm{H}\right]^{+}, 242(50)\left[\mathrm{BPh}_{3}+\mathrm{H}\right]^{+}, 481(45)\left[\left(\mathrm{Im}^{\mathrm{Bn}}\right)_{2} \mathrm{BPh}_{2}\right]^{+}$. Anal. Calcd. for $\mathrm{C}_{28} \mathrm{H}_{25} \mathrm{BN}_{2}$ : C 84.01, H 6.29, N 7.00. Found: C 83.72, H 6.03, N 7.06.

\subsubsection{Synthesis of $\left(\mathrm{Im}^{\mathrm{Bn}} \mathrm{BPh}_{2}\right)_{2}$ (5)}

In a 100-mL PTFE vessel equipped with a magnetic stir bar, Compound $4(0.360 \mathrm{~g}, 0.900 \mathrm{mmol})$, silver oxide $\left(\mathrm{Ag}_{2} \mathrm{O}, 0.104 \mathrm{~g}, 0.450 \mathrm{mmol}\right)$, and $\mathrm{CH}_{3} \mathrm{CN}(25 \mathrm{~mL})$ were added. The reaction mixture was heated in the microwave reactor following a pre-set heating ramp, up to $80^{\circ} \mathrm{C}$. Once the temperature was reached, the reaction proceeded for $1 \mathrm{~h}$ and then it was cooled following a pre-set cooling ramp, to room temperature. All the steps were performed always under magnetic stirring. At the end, the 
mixture was filtered and the obtained mother liquors were dried at reduced pressure to give the oily brownish residue $\left(\mathrm{Im}^{\mathrm{Bn}} \mathrm{BPh}_{2}\right)_{2}$ (5) in $54 \%$ yield $(0.157 \mathrm{~g})$. IR $\left(\mathrm{cm}^{-1}\right): 3161 \mathrm{~m}, 3143 \mathrm{~m}, 3113 \mathrm{sh}, 3087 \mathrm{~m}$, $3064 \mathrm{~m}, 3038 \mathrm{~m}, 3024 \mathrm{~m}, 3010 \mathrm{~m}, 2999 \mathrm{~m}, 2972 \mathrm{~m}, 2938 \mathrm{wbr}(\mathrm{C}-\mathrm{H}) ; 1600 \mathrm{~m}, 1587 \mathrm{~m}, 1571 \mathrm{~m}, 1534 \mathrm{~s}, 1509 \mathrm{~s}$, $1496 \mathrm{sbr}(\mathrm{C}=\mathrm{C} / \mathrm{C}=\mathrm{N}) .{ }^{1} \mathrm{H}-\mathrm{NMR}\left(\mathrm{DMSO}-d_{6}, 293 \mathrm{~K}\right): \delta 5.18\left(\mathrm{~s}, 2 \mathrm{H}, \mathrm{CH}_{2}\right), 6.91(\mathrm{~s}, 1 \mathrm{H}, 4-\mathrm{CH}$ or $5-\mathrm{CH})$, 7.18-7.36 (m, 15H, ArH), 7.77 (s, 1H, 4-CH or 5-CH). ${ }^{1} \mathrm{H}-\mathrm{NMR}\left(\mathrm{CDCl}_{3}, 293 \mathrm{~K}\right): \delta 5.13\left(\mathrm{~s}, 2 \mathrm{H}, \mathrm{CH}_{2}\right), 6.92$ (s, 1H, 4-CH or 5-CH), 7.11-7.44 (m, 15H, ArH), $7.67(\mathrm{~s}, 1 \mathrm{H}, 4-\mathrm{CH}$ or $5-\mathrm{CH}) .{ }^{13} \mathrm{C}\left\{{ }^{1} \mathrm{H}\right\}-\mathrm{NMR}$ (DMSO- $d_{6}$, $293 \mathrm{~K}): \delta 50.04\left(\mathrm{CH}_{2} \mathrm{Ph}\right), 120.14,127.98,128.28,128.79,128.94,129.17,130.56,134.47(\mathrm{CH}), 159.18(2-\mathrm{C})$. ${ }^{11} \mathrm{~B}-\mathrm{NMR}$ (DMSO- $d_{6}, 293 \mathrm{~K}$ ): $\delta 1.43$ (s). ESI-MS (major positive ions, $\mathrm{CH}_{3} \mathrm{CN}$ ), $\mathrm{m} / \mathrm{z}(\%)$ : $91(95)\left[\mathrm{C}_{7} \mathrm{H}_{7}\right]^{+}$, 159 (100) $\left[\mathrm{HIm}^{\mathrm{Bn}}+\mathrm{H}\right]^{+}$. Elemental analysis for $\mathrm{C}_{29} \mathrm{H}_{27} \mathrm{AgBN}_{2}$ (\%): calculated: $\mathrm{H}$ 5.94, $\mathrm{C}$ 82.01, N 8.69; found: H 6.04, C 81.27, N 8.89.

\subsection{Crystallographic Data Collection and Refinement}

A suitable crystal covered with a layer of hydrocarbon/Paratone- $N$ oil was selected and mounted on a Cryo-loop and immediately placed in the low temperature nitrogen stream. X-ray intensity data were measured at 100(2) K on a Bruker SMART APEX II CCD area detector system equipped with an Oxford Cryosystems 700 series cooler, a graphite monochromator, and a Mo K $\alpha$ fine-focus sealed tube $(\lambda=0.71073 \AA$ ). Intensity data were processed using the Bruker ApexII program suite. Absorption corrections were applied by using SADABS. Initial atomic positions were located by direct methods using XS, and the structures of the compounds were refined by the least-squares method using SHELXL [99]. All the non-hydrogen atoms were refined anisotropically. The hydrogen atoms attached to boron (B-H) were located in difference Fourier maps, included and refined freely with isotropic displacement parameters. All the other hydrogen atoms were placed at calculated positions and refined using a riding model. X-ray structural figures were generated using Olex2 [100]. The CCDC 2010217-2010218 contain the supplementary crystallographic data. These data can be obtained free of charge via http://www.ccdc.cam.ac.uk/conts/retrieving.html or from the Cambridge Crystallographic Data Centre (CCDC), 12 Union Road, Cambridge, CB2 1EZ, UK).

\section{Conclusions}

Two imidazolium-trihydridoborate adducts were obtained by addition of $\mathrm{BH}_{3} \bullet \mathrm{THF}$ to N-benzyland $N$-mesitylimidazoles. In addition, two imidazolium-triphenylborates were obtained by displacement of one phenyl group of ammonium tetraphenylborate reacting with methyl- or benzyl-imidazoles. 3-Benzyl-imidazolium-1-yl)trihydridoborate and (3-mesityl-imidazolium-1-yl)trihydridoborate were also characterized by X-ray crystallography. The reactivity of these new compounds as carbene precursors was investigated and a new dimeric carbene-borate adduct was obtained via a microwave-assisted procedure. The intermolecular rearrangement pathway to the head-to-tail imidazabole dimer prevented the isolation of this type of compounds and the development of their characteristic NHC chemistry.

Author Contributions: Conceptualization, C.S.; Data curation, R.V. and H.V.R.D.; Formal analysis, L.B. and H.V.R.D.; Investigation, M.P.; Methodology, M.P.; Supervision, M.P. and C.S.; Writing - original draft, M.P., H.V.R.D. and C.S. All authors have read and agreed to the published version of the manuscript.

Funding: This research was supported by the University of Camerino (FAR 2019). H.V.R.D. is thankful for the financial support by the Robert A. Welch Foundation (Grant Y-1289).

Acknowledgments: We are grateful to CIRCMSB (Consorzio Interuniversitario di Ricerca in Chimica dei Metalli nei Sistemi Biologici).

Conflicts of Interest: The authors declare no conflict of interest. 


\section{References}

1. Arduengo, A.J.; Dias, H.V.R.; Harlow, R.L.; Kline, M. Electronic stabilization of nucleophilic carbenes. J. Am. Chem. Soc. 1992, 114, 5530-5534. [CrossRef]

2. Igau, A.; Grutzmacher, H.; Baceiredo, A.; Bertrand, G. Analogous.alpha.,.alpha.'-bis-carbenoid, triply bonded species: Synthesis of a stable.lambda.3-phosphino carbene-.lambda.5-phosphaacetylene. J. Am. Chem. Soc. 1988, 110, 6463-6466. [CrossRef]

3. Arduengo, A.J.; Harlow, R.L.; Kline, M. A stable crystalline carbene. J. Am. Chem. Soc. 1991, 113, $361-363$. [CrossRef]

4. Hopkinson, M.N.; Richter, C.; Schedler, M.; Glorius, F. An overview of N-heterocyclic carbenes. Nature 2014, 510, 485-496. [CrossRef]

5. Martin, C.D.; Soleilhavoup, M.; Bertrand, G. Carbene-Stabilized Main Group Radicals and Radical Ions. Chem. Sci. 2013, 4, 3020-3030. [CrossRef] [PubMed]

6. Hahn, F.E.; Jahnke, M.C. Heterocyclic Carbenes: Synthesis and Coordination Chemistry. Angew. Chem. Int. Ed. 2008, 47, 3122-3172. [CrossRef] [PubMed]

7. Nolan, S.P.N-Heterocyclic Carbenes in Synthesis; Wiley-VCH Verlag GmbH \& Co. KGaA: Weinheim, Germany, 2006.

8. Dröge, T.; Glorius, F. The Measure of All Rings-N-Heterocyclic Carbenes. Angew. Chem. Int. Ed. 2010, 49, 6940-6952. [CrossRef]

9. Hahn, F.E. Heterocyclic Carbenes. Angew. Chem. Int. Ed. 2006, 45, 1348-1352. [CrossRef]

10. Díez-González, S. N-Heterocyclic Carbenes: From Laboratory Curiosities to Efficient Synthetic Tools: Edition 2; Royal Society of Chemistry: Cambridge, UK, 2017.

11. Öfele, K.; Herrmann, W.A.; Mihalios, D.; Elison, M.; Herdtweck, E.; Scherer, W.; Mink, J. Multiple bonds between Main-Group elements and transition metals. CXXVI. Heterocyclene-carbenes as phosphine-analog ligands in metal complexes. J. Organomet. Chem. 1993, 459, 177-184. [CrossRef]

12. Kühl, O. Functionalised N-Heterocyclic Carbene Complexes; John Wiley \& Sons Ltd.: Chichester, UK, 2010.

13. Zeng, X.; Soleilhavoup, M.; Bertrand, G. Gold-Catalyzed Intermolecular Markovnikov Hydroamination of Allenes with Secondary Amines. Org. Lett. 2009, 11, 3166-3169. [CrossRef]

14. Crabtree, R.H. NHC ligands versus cyclopentadienyls and phosphines as spectator ligands in organometallic catalysis. J. Organomet. Chem. 2005, 690, 5451-5457. [CrossRef]

15. Nesterov, V.; Reiter, D.; Bag, P.; Frisch, P.; Holzner, R.; Porzelt, A.; Inoue, S. NHCs in Main Group Chemistry. Chem. Rev. 2018, 118, 9678-9842. [CrossRef] [PubMed]

16. Arduengo, A.J.; Bertrand, G. Carbenes Introduction. Chem. Rev. 2009, 109, 3209-3210. [CrossRef] [PubMed]

17. Doddi, A.; Peters, M.; Tamm, M. N-Heterocyclic Carbene Adducts of Main Group Elements and Their Use as Ligands in Transition Metal Chemistry. Chem. Rev. 2019, 119, 6994-7112. [CrossRef]

18. Arnold, P.L.; Casely, I.J. F-Block N-Heterocyclic Carbene Complexes. Chem. Rev. 2009, 109, 3599-3611. [CrossRef]

19. Cazin, C.S.J. N-Heterocyclic Carbenes in Transition Metal Catalysis and Organocatalysis; Springer Science \& Business Media: Dordrecht, The Netherlands, 2011; Volume 32.

20. Lin, J.C.Y.; Huang, R.T.W.; Lee, C.S.; Bhattacharyya, A.; Hwang, W.S.; Lin, I.J.B. Coinage Metal-N-Heterocyclic Carbene Complexes. Chem. Rev. 2009, 109, 3561-3598. [CrossRef]

21. Dash, C.; Kroll, P.; Yousufuddin, M.; Dias, H.V.R. Isolable, gold carbonyl complexes supported by N-heterocyclic carbenes. Chem. Commun. 2011, 47, 4478. [CrossRef]

22. Celik, M.A.; Dash, C.; Adiraju, V.A.; Das, A.; Yousufuddin, M.; Frenking, G.; Dias, H.V.R. End-On and Side-On $\pi$-Acid Ligand Adducts of Gold(I): Carbonyl, Cyanide, Isocyanide, and Cyclooctyne Gold(I) Complexes Supported by N-Heterocyclic Carbenes and Phosphines. Inorg. Chem. 2012, 52, 729-742. [CrossRef]

23. Dash, C.; Das, A.; Yousufuddin, M.; Dias, H.V.R. Isolable, Copper(I) Dicarbonyl Complexes Supported by N-Heterocyclic Carbenes. Inorg. Chem. 2013, 52, 1584-1590. [CrossRef]

24. Dash, C.; Yousufuddin, M.; Cundari, T.R.; Dias, H.V.R.; Dias, H.V.R. Gold-Mediated Expulsion of Dinitrogen from Organic Azides. J. Am. Chem. Soc. 2013, 135, 15479-15488. [CrossRef]

25. Wang, G.; Ponduru, T.T.; Wang, Q.; Zhao, L.; Frenking, G.; Dias, H.V.R. Heterobimetallic Complexes Featuring $\mathrm{Fe}(\mathrm{CO}) 5$ as a Ligand on Gold. Chem. - A Eur. J. 2017, 23, 17222-17226. [CrossRef] [PubMed] 
26. Dash, C.; Wang, G.; Muñoz-Castro, A.R.; Ponduru, T.T.; Zacharias, A.O.; Yousufuddin, M.; Dias, H.V.R. Organic Azide and Auxiliary-Ligand-Free Complexes of Coinage Metals Supported by N-Heterocyclic Carbenes. Inorg. Chem. 2019, 59, 2188-2199. [CrossRef] [PubMed]

27. Smith, C.A.; Narouz, M.R.; Lummis, P.A.; Singh, I.; Nazemi, A.; Li, C.H.; Crudden, C.M. N-Heterocyclic Carbenes in Materials Chemistry. Chem. Rev. 2019, 119, 4986-5056. [CrossRef] [PubMed]

28. Rovis, T.; Nolan, S.P. Stable Carbenes: From 'Laboratory Curiosities' to Catalysis Mainstays. Synlett 2013, 24, 1188-1189. [CrossRef]

29. Schaper, L.-A.; Hock, S.J.; Herrmann, W.A.; Kuehn, F.E. Synthesis and Application of Water-Soluble NHC Transition-Metal Complexes. Angew. Chem. int. Ed. 2013, 44, 270-289. [CrossRef]

30. He, Y.; Lv, M.-F.; Cai, C. A simple procedure for polymer-supported N-heterocyclic carbene silver complex via click chemistry: An efficient and recyclable catalyst for the one-pot synthesis of propargylamines. Dalton Trans. 2012, 41, 12428-12433. [CrossRef]

31. Li, Y.; Chen, X.; Song, Y.; Fang, L.; Zou, G. Well-defined N-heterocyclic carbene silver halides of 1-cyclohexyl-3-arylmethylimidazolylidenes: Synthesis, structure and catalysis in A3-reaction of aldehydes, amines and alkynes. Dalton Trans. 2011, 40, 2046. [CrossRef]

32. Herrmann, W.A. N-heterocyclic carbenes: A new concept in organometallic catalysis. Angew. Chem. Int. Ed. 2002, 41, 1290-1309. [CrossRef]

33. Glorius, F.; Glorius, F. N-Heterocyclic Carbenes in Transition Metal Catalysis; Springer-Verlag Berlin Heidelberg: Heidelberg, Germany, 2007.

34. Marion, N.; Nolan, S.P.; Díez-González, S. N-Heterocyclic Carbenes as Organocatalysts. Angew. Chem. Int. Ed. 2007, 46, 2988-3000. [CrossRef]

35. Izquierdo, J.; Hutson, G.E.; Cohen, D.T.; Scheidt, K.A. A continuum of progress: Applications of N-hetereocyclic carbene catalysis in total synthesis. Angew. Chem. Int. Ed. 2012, 51, 11686-11698. [CrossRef]

36. Bugaut, X.; Glorius, F. Organocatalytic umpolung: N-heterocyclic carbenes and beyond. Chem. Soc. Rev. 2012, 41, 3511. [CrossRef] [PubMed]

37. Díez-González, S.; Marion, N.; Nolan, S.P. N-Heterocyclic Carbenes in Late Transition Metal Catalysis. Chem. Rev. 2009, 109, 3612-3676. [CrossRef] [PubMed]

38. Kantchev, E.A.B.; O'Brien, C.J.; Organ, M.G. Palladium Complexes of N-Heterocyclic Carbenes as Catalysts for Cross-Coupling Reactions - A Synthetic Chemist's Perspective. Angew. Chem. Int. Ed. 2007, 38, 2768-2813. [CrossRef] [PubMed]

39. Wang, H.M.J.; Lin, I.J.B. Facile Synthesis of Silver(I)-Carbene Complexes. Useful Carbene Transfer Agents. Organometallics 1998, 17, 972-975. [CrossRef]

40. Mjos, K.D.; Orvig, C. Metallodrugs in Medicinal Inorganic Chemistry. Chem. Rev. 2014, 114, 4540-4563. [CrossRef] [PubMed]

41. Aher, S.B.; Muskawar, P.N.; Thenmozhi, K.; Bhagat, P.R. Recent developments of metal N-heterocyclic carbenes as anticancer agents. Eur. J. Med. Chem. 2014, 81, 408-419. [CrossRef] [PubMed]

42. Ceresa, C.; Bravin, A.; Cavaletti, G.; Pellei, M.; Santini, C. The combined therapeutical effect of metal-based drugs and radiation therapy: The present status of research. Curr. Med. Chem. 2014, 21, 2237-2265. [CrossRef]

43. Budagumpi, S.; Haque, R.A.; Endud, S.; Rehman, G.U.; Salman, A.W. Biologically Relevant Silver(I)-N-Heterocyclic Carbene Complexes: Synthesis, Structure, Intramolecular Interactions, and Applications. Eur. J. Inorg. Chem. 2013, 2013, 4367-4388. [CrossRef]

44. Liu, W.; Gust, R. Metal N-heterocyclic carbene complexes as potential antitumor metallodrugs. Chem. Soc. Rev. 2013, 42, 755-773. [CrossRef]

45. Monteiro, D.C.F.; Phillips, R.M.; Crossley, B.D.; Fielden, J.; Willans, C.E. Enhanced cytotoxicity of silver complexes bearing bidentate N-heterocyclic carbeneligands. Dalton Trans. 2012, 41, 3720. [CrossRef]

46. Hindi, K.M.; Panzner, M.J.; Tessier, C.A.; Cannon, C.L.; Youngs, W.J. The Medicinal Applications of Imidazolium Carbene-Metal Complexes. Chem. Rev. 2009, 109, 3859-3884. [CrossRef] [PubMed]

47. Teyssot, M.-L.; Jarrousse, A.-S.; Manin, M.; Chevry, A.; Roche, S.; Norre, F.; Beaudoin, C.; Morel, L.; Boyer, D.; Mahiou, R.; et al. Metal-NHC complexes: A survey of anti-cancer properties. Dalton Trans. 2009, 35, 6894. [CrossRef] [PubMed]

48. Hartinger, C.G.; Dyson, P.J. Bioorganometallic chemistry—from teaching paradigms to medicinal applications. Chem. Soc. Rev. 2009, 38, 391-401. [CrossRef] [PubMed] 
49. Porchia, M.; Pellei, M.; Marinelli, M.; Tisato, F.; Del Bello, F.; Santini, C. New insights in Au-NHCs complexes as anticancer agents. Eur. J. Med. Chem. 2018, 146, 709-746. [CrossRef] [PubMed]

50. Arduengo, A.J.; Goerlich, J.R.; Marshall, W.J. A stable diaminocarbene. J. Am. Chem. Soc. 1995, 117, 11027-11028. [CrossRef]

51. Alder, R.W.; Allen, P.R.; Murray, M.; Orpen, A.G. Bis(diisopropylamino)carbene. Angew. Chem. Int. Ed. 1996, 35, 1121-1123. [CrossRef]

52. Santini, C.; Marinelli, M.; Pellei, M. Boron-Centered Scorpionate-Type NHC-Based Ligands and Their Metal Complexes. Eur. J. Inorg. Chem. 2016, 2016, 2312-2331. [CrossRef]

53. Weiss, A.; Pritzkow, H.; Siebert, W. Synthesis, Structures and Reactivity ofN-Borane-Protected 1,1'-Bisimidazoles with Different Bridging Functions. Eur. J. Inorg. Chem. 2002, 2002, 1607-1614. [CrossRef]

54. Kernbach, U.; Ramm, M.; Luger, P.; Fehlhammer, W.P. A Chelating Triscarbene Ligand and Its Hexacarbene Iron Complex. Angew. Chem. Int. Ed. 1996, 35, 310-312. [CrossRef]

55. Lapointe, R.E.; Roof, G.R.; Abboud, K.A.; Klosin, J. New Family of Weakly Coordinating Anions. J. Am. Chem. Soc. 2000, 122, 9560-9561. [CrossRef]

56. Asada, T.; Hoshimoto, Y.; Ogoshi, S. Rotation-Triggered Transmetalation on a Heterobimetallic Cu/Al N-Phosphine-Oxide-Substituted Imidazolylidene Complex. J. Am. Chem. Soc. 2020, 142, 9772-9784. [CrossRef]

57. Vagedes, D.; Kehr, G.; König, D.; Wedeking, K.; Fröhlich, R.; Erker, G.; Mück-Lichtenfeld, C.; Grimme, S. Formation of Isomeric BAr3 Adducts of 2-Lithio-N-methylimidazole. Eur. J. Inorg. Chem. 2002, 2002, 2015-2021. [CrossRef]

58. Wacker, A.; Pritzkow, H.; Siebert, W. Nucleophilic Substitution Reactions with the 3-Borane-1,4,5-trimethylimidazol-2-ylidene Anion. - Unexpected Formation of an Imidazabole Isomer. Eur. J. Inorg. Chem. 1999, 5, 789-793. [CrossRef]

59. Wacker, A.; Pritzkow, H.; Siebert, W. Borane-substituted imidazol-2-ylidenes. Syntheses, structures, and reactivity. Eur. J. Inorg. Chem. 1998, 6, 843-849. [CrossRef]

60. Padilla-Martínez, I.I.; Martínez-Martínez, F.J.; López-Sandoval, A.; Girón-Castillo, K.I.; Brito, M.A.; Contreras, R. New imidazabole derivatives: Dimers of carbene-borane adducts. Eur. J. Inorg. Chem. 1998, 10, 1547-1553.

61. Okada, K.; Suzuki, R.; Oda, M. Novel boron-nitrogen containing compounds from the reaction of organolithiums with complexes between dimesitylfluoroborane and six- or five-membered aza aromatic compounds. J. Chem. Soc., Chem. Commun. 1995, 20, 2069-2070. [CrossRef]

62. Padilla-Martínez, I.I.; Ariza-Castolo, A.; Contreras, R. NMR Study of isolobal N-CH3+, N-BH3 and N-BF3 imidazole derivatives. Magn. Reson. Chem. 1993, 31, 189-193. [CrossRef]

63. Nasr, A.; Winkler, A.; Tamm, M. Anionic N-heterocyclic carbenes: Synthesis, coordination chemistry and applications in homogeneous catalysis. Coord. Chem. Rev. 2016, 316, 68-124. [CrossRef]

64. Wacker, A.; Yan, C.G.; Kaltenpoth, G.; Ginsberg, A.; Arif, A.M.; Ernst, R.; Pritzkow, H.; Siebert, W. Metal complexes of anionic 3-borane-1-alkylimidazol-2-ylidene derivatives. J. Organomet. Chem. 2002, 641, 195-202. [CrossRef]

65. Liu, W.-C.; Liu, Y.-H.; Lin, T.-S.; Peng, S.-M.; Chiu, C.-W. 1,2-Migration of N-Diarylboryl Imidazol-2-ylidene through Intermolecular Radical Process. Inorg. Chem. 2017, 56, 10543-10548. [CrossRef]

66. Padilla-Martínez, I.I.; Rosalez-Hoz, M.D.J.; Contreras, R.; Kerschl, S.; Wrackmeyer, B. From Azole-Borane Adducts to Azaboles-Molecular Structure of an Imidazabole. Eur. J. Inorg. Chem. 1994, 127, 343-346. [CrossRef]

67. Vagedes, D.; Erker, G.; Kehr, G.; Bergander, K.; Kataeva, O.; Fröhlich, R.; Grimme, S.; Mück-Lichtenfeld, C. Tris(pentafluorophenyl)borane adducts of substituted imidazoles: Conformational features and chemical behavior upon deprotonation. Dalton Trans. 2003, 7, 1337-1344. [CrossRef]

68. Arrowsmith, M.; Heath, A.; Hill, M.S.; Hitchcock, P.B.; Kociok-Köhn, G. Tris(imidazolin-2-ylidene-1-yl)borate Complexes of the Heavier Alkaline Earths: Synthesis and Structural Studies. Organometallics 2009, 28, 4550-4559. [CrossRef]

69. Crudden, C.M.; Allen, D.P. Stability and reactivity of N-heterocyclic carbene complexes. Co-ord. Chem. Rev. 2004, 248, 2247-2273. [CrossRef] 
70. Huang, S.; Zhang, W.; Liu, T.; Wang, K.; Qi, X.; Zhang, J.; Zhang, Q. TowardsN-Alkylimidazole Borane-based Hypergolic Fuels. Chem. - Asian J. 2016, 11, 3528-3533. [CrossRef]

71. Santini, C.; Pellei, M.; Gioia Lobbia, G.; Papini, G. Synthesis and properties of poly(pyrazolyl)borate and related boron-centered scorpionate ligands. Part A: Pyrazole-based systems. Mini-Rev. Org. Chem. 2010, 7 , 84-124. [CrossRef]

72. Pellei, M.; Lobbia, G.G.; Papini, G.; Santini, C. Synthesis and Properties of Poly(pyrazolyl)borate and Related Boron-Centered Scorpionate Ligands. Part B: Imidazole-, Triazole- and Other Heterocycle-Based Systems. Mini-Reviews Org. Chem. 2010, 7, 173-203. [CrossRef]

73. Fränkel, R.; Birg, C.; Kernbach, U.; Habereder, T.; Noth, H.; Fehlhammer, W.P. A Homoleptic Carbene-Lithium Complex. Angew. Chem., Int. Ed. 2001, 40, 1907-1910. [CrossRef]

74. Frankel, R.; Kernbach, U.; Bakola-Christianopoulou, M.; Plaia, U.; Suter, M.; Ponikwar, W.; Noth, H.; Moinet, C.; Fehlhammer, W.P. Homoleptic carbene complexes. Part VIII. Hexacarbene complexes. J. Organomet. Chem. 2001, 530-545. [CrossRef]

75. Fränkel, R.; Kniczek, J.; Ponikwar, W.; Noth, H.; Polborn, K.; Fehlhammer, W.P. Homoleptic carbene complexes: Part IX. Bis(imidazolin-2-ylidene-1-yl)borate complexes of palladium(II), platinum(II) and gold(I). Inorg. Chim. Acta 2001, 312, 23-39.

76. Nieto, I.; Bontchev, R.P.; Smith, J.M. Synthesis of a Bulky Bis(carbene)borate Ligand - Contrasting Structures of Homoleptic Nickel(II) Bis(pyrazolyl)borate and Bis(carbene)borate Complexes. Eur. J. Inorg. Chem. 2008, 2008, 2476-2480. [CrossRef]

77. Biffis, A.; Lobbia, G.G.; Papini, G.; Pellei, M.; Santini, C.; Scattolin, E.; Tubaro, C. Novel scorpionate-type triscarbene ligands and their silver and gold complexes. J. Organomet. Chem. 2008, 693, 3760-3766. [CrossRef]

78. Papini, G.; Bandoli, G.; Dolmella, A.; Lobbia, G.G.; Pellei, M.; Santini, C. New homoleptic carbene transfer ligands and related coinage metal complexes. Inorg. Chem. Commun. 2008, 11, 1103-1106. [CrossRef]

79. Papini, G.; Pellei, M.; Lobbia, G.G.; Burini, A.; Santini, C. Sulfonate- or carboxylate-functionalized N-heterocyclic bis-carbene ligands and related water soluble silver complexes. Dalton Trans. 2009, 6985. [CrossRef]

80. Giorgetti, M.; Aquilanti, G.; Pellei, M.; Gandin, V. The coordination core of Ag( i) N-heterocyclic carbene (NHC) complexes with anticancer properties as revealed by synchrotron radiation X-ray absorption spectroscopy. J. Anal. At. Spectrom. 2014, 29, 491-497. [CrossRef]

81. Pellei, M.; Gandin, V.; Marinelli, M.; Marzano, C.; Yousufuddin, M.; Dias, H.V.R.; Santini, C. Synthesis and Biological Activity of Ester- and Amide-Functionalized Imidazolium Salts and Related Water-Soluble Coinage Metal N-Heterocyclic Carbene Complexes. Inorg. Chem. 2012, 51, 9873-9882. [CrossRef]

82. Gandin, V.; Pellei, M.; Marinelli, M.; Marzano, C.; Dolmella, A.; Giorgetti, M.; Santini, C. Synthesis and in vitro antitumor activity of water soluble sulfonate- and ester-functionalized silver(I) N-heterocyclic carbene complexes. J. Inorg. Biochem. 2013, 129, 135-144. [CrossRef]

83. Maria, L.; Paulo, A.; Santos, I.C.; Santos, I.; Kurz, P.; Spingler, B.; Alberto, R. Very Small and Soft Scorpionates: Water Stable Technetium Tricarbonyl Complexes Combining a Bis-agostic (k3-H, H, S) Binding Motif with Pendant and Integrated Bioactive Molecules. J. Am. Chem. Soc. 2006, 128, 14590-14598. [CrossRef]

84. Lu, D.; Tang, H. Theoretical survey of the ligand tunability of poly(azolyl)borates. Phys. Chem. Chem. Phys. 2015, 17, 17027-17033. [CrossRef]

85. Pellei, M.; Papini, G.; Lobbia, G.G.; Ricci, S.; Yousufuddin, M.; Dias, H.V.R.; Santini, C.; Dias, H.V.R. Scorpionates bearing nitro substituents: Mono-, bis- and tris-(3-nitro-pyrazol-1-yl)borate ligands and their copper(i) complexes. Dalton Trans. 2010, 39, 8937. [CrossRef]

86. Dias, H.V.R.; Alidori, S.; Lobbia, G.G.; Papini, G.; Pellei, M.; Santini, C.; Dias, H.V.R. Small Scorpionate Ligands: Silver(I)-Organophosphane Complexes of 5-CF3-Substituted Scorpionate Ligand Combining a B-H・Ag Coordination Motif. Inorg. Chem. 2007, 46, 9708-9714. [CrossRef] [PubMed]

87. Meisters, M.; VandeBerg, J.T.; Cassaretto, F.P.; Posvic, H.; Moore, C.E. Studies in the tetraarylborates: Part V. The influence of substituents on the stability of tetraarylborates. Anal. Chim. Acta 1970, 49, 481-485. [CrossRef]

88. Bakshi, P.K.; Linden, A.; Vincent, B.R.; Roe, S.P.; Adhikesavalu, D.; Cameron, T.S.; Knop, O. Crystal chemistry of tetraradial species. Part 4. Hydrogen bonding to aromatic $\pi$ systems: Crystal structures of fifteen tetraphenylborates with organic ammonium cations. Can. J. Chem. 1994, 72, 1273-1293. [CrossRef] 
89. Belanger, S.; Beauchamp, A.L. (1-Methylimidazole- N 3 )triphenylboron. Acta Crystallogr. Sect. C Cryst. Struct. Commun. 1998, 54, IUC9800057. [CrossRef]

90. Bélanger-Chabot, G.; Kaplan, S.M.; Deokar, P.; Szimhardt, N.; Haiges, R.; Christe, K.O. Synthesis and Characterization of Nitro-, Trinitromethyl-, and Fluorodinitromethyl-Substituted Triazolyl- and Tetrazolyl-trihydridoborate Anions. Chem. - A Eur. J. 2017, 23, 13087-13099. [CrossRef]

91. Ridlen, S.G.; Kulkarni, N.; Dias, H.V.R. Monoanionic, Bis(pyrazolyl)methylborate [(Ph3B)CH(3,5-(CH3)2Pz)2)]-as a Supporting Ligand for Copper(I)-ethylene, cis-2-Butene, and Carbonyl Complexes. Inorg. Chem. 2017, 56, 7237-7246. [CrossRef] [PubMed]

92. Good, C.D.; Ritter, D.M. Alkenylboranes. II. Improved Preparative Methods and New Observations on Methylvinylboranes. J. Am. Chem. Soc. 1962, 84, 1162-1166. [CrossRef]

93. Winkelmann, O.H.; Navarro, O. Microwave-Assisted Synthesis of N-Heterocyclic Carbene- Palladium(II) Complexes. Adv. Synth. Catal. 2010, 352, 212-214. [CrossRef]

94. Curran, D.P.; Solovyev, A.; Brahmi, M.M.; Fensterbank, L.; Malacria, M.; Lacôte, E. Synthesis and Reactions of N-Heterocyclic Carbene Boranes. Angew. Chem. Int. Ed. 2011, 50, 10294-10317. [CrossRef]

95. Wrackmeyer, B. Nuclear Magnetic Resonance Spectroscopy of Boron Compounds Containing Two-, Threeand Four-Coordinate Boron. Annual Reports on NMR Spectroscopy 1988, 20, 61-203. [CrossRef]

96. Kronig, S.; Theuergarten, E.; Daniliuc, C.; Jones, P.G.; Tamm, M. Anionic N-Heterocyclic Carbenes That Contain a Weakly Coordinating Borate Moiety. Angew. Chem. Int. Ed. 2012, 51, 3240-3244. [CrossRef] [PubMed]

97. Kolychev, E.L.; Kronig, S.; Brandhorst, K.; Freytag, M.; Jones, P.G.; Tamm, M. Iridium(I) Complexes with Anionic N-Heterocyclic Carbene Ligands as Catalysts for the Hydrogenation of Alkenes in Nonpolar Media. J. Am. Chem. Soc. 2013, 135, 12448-12459. [CrossRef]

98. Liu, J.; Chen, J.; Zhao, J.; Zhao, Y.; Li, L.; Zhang, H. A Modified Procedure for the Synthesis of 1-Arylimidazoles. Synthesis 2003, 17, 2661-2666. [CrossRef]

99. Sheldrick, G.M. A short history ofSHELX. Acta Crystallogr. Sect. A Found. Crystallogr. 2007, 64, 112-122. [CrossRef]

100. Dolomanov, O.; Bourhis, L.J.; Gildea, R.; Howard, J.A.; Puschmann, H. OLEX2: A complete structure solution, refinement and analysis program. J. Appl. Crystallogr. 2009, 42, 339-341. [CrossRef]

Sample Availability: Samples of the compounds are available from the authors.

(C) 2020 by the authors. Licensee MDPI, Basel, Switzerland. This article is an open access article distributed under the terms and conditions of the Creative Commons Attribution (CC BY) license (http://creativecommons.org/licenses/by/4.0/). 